\title{
Patriarchy Culture and Injustice for Women in Politics
}

\author{
Fredik Lambertus Kollo* and Sunarso Sunarso \\ Universitas Negeri Yogyakarta \\ Yogyakarta, Indonesia \\ *fredikkollo@yahoo.co.id
}

\begin{abstract}
Injustice to the woman is often happens in every aspect of life. One of them is the injustice to the woman in politics. The purpose of this research is to know the influence of patriarchy culture through the injustice of woman in politics. This research based on the idea that patriarchy culture puts woman in the second place after man. The politic system tends to be influenced by patriarchy culture so woman got less access to the politics. Woman doesn't have chance to manage strategic position in politics, this thing shows that man is always dominating the politics. The object of this research is at NonGovernment Organization Legal Aid Institute of KupangIndonesia Woman Association (LSM LBH APIK). The method used in this research was descriptive qualitative method. The results of research showed that the opinion of society to woman was not more than to take care of house works. There are some injustices of women in politics. The first is the lack of politic education for woman. After that, there is lack of political party. Then, the third one is the woman doesn't have chance to manage strategic position in decision making process.
\end{abstract}

Keywords-Patriarchy culture; politics; woman injustice

\section{INTRODUCTION}

The women movement in politics has been occurred since a long time, but it should face many challenges. Woman who wants to enroll in politics should found the fact that politics, public, culture, and social is not kind to woman [1].

A country which still adopt patriarchy system shows that men are more dominating than women so the women always be seen at second position after men which makes men always take decisions [2]. Yusilia stated that patriarchy culture refers to the condition of social culture which gives perspective that men are more superior to women [3]. The journey of patriarchy culture is much stronger when there is a change of social to society so it is developed become capitalism society and as the result society will see the rightest human norm if it is seen from men's side [4]. Patriarchy society in the early establishes the human civilization and considers that men are stronger than women whether in the personal life, family, society, or state. The biological difference between man and woman is considered as the beginning of patriarchy culture forming [5]. Patriarchy is a social construction and ideology which consider men are more advantageous than women [6]. Patriarchy gives authority to other people including young man so it needs control and coordination to woman who crosses the limits of culture and religion [7]. Woman usually does the house works but the way of patriarchy production is not defined in the term of house works but in the relation with the works [8].
Generally, at Kupang City, East Nusa Tenggara Province Indonesia, there are some people in their life still in touch with patriarchy culture so in politics is also influenced by patriarchy culture. Pranowo stated that the struggle of woman is only to become like man in patriarchy culture [9]. The general election at Kupang City at 2017 showed that the dominant candidates who got supports from political party were men and women didnot get the supports. From the cultural aspect, it also shows that men are more primary then women. Yusilia stated that culture aspect which is near with the society is very dominant with the domination of men to women [3]. This research focus on the influence of patriarchy culture to woman in politics, because many woman candidates who tries to be elected as executive member (major), but they didnot get supports from political party. Badawi stated that women rarely get important position in decision making process, especially in the structure at a political party [10].

\section{METHOD}

This research used descriptive qualitative method. This research used five informants, which includes directors, deputy directors, secretaries, members and one of the participants and all of them are member of Non-Government Organization Legal Aid Institution Kupang-Indonesia Woman Association (LSM LBH APIK). To confirm the data validity, this research used triangulation method. Triangulation method was conducted by the researcher to confirm the data with the informants through the interview results, which the informants are the member of Non-Government Organization Legal Aid Institution Kupang-Indonesia Woman Association (LSM LBH APIK).

\section{RESUlTS AND DISCUSSION}

In this discussion, there are some findings related to patriarchy culture and the woman injustice in politics. Patriarchy culture still near with the life of society, so it was found that women always got challenges and it was not easy for women to participate in politics. Nurmila stated that patriarchy culture had created injustice in the relation of gender [11]. Rafni stated that the involvement of woman in politics, especially in legislative shows the low representation of woman in politics [12].

Women believe that politics is the world of men, so that women do not have access to the political sphere. The patriarchal society always positions women as the second position after men. in certain political activities of men who 
always have a priority over women. women always lose political fights, especially in legislative elections. The government opened up space for women through $30 \%$ of the quota, but women have not yet fulfilled it. Panday stated that woman who wants to be a member of legislative should fulfill the requirements of quota system [13].

Women have ability to lead but they do not get chance. Woman has also declared herself to participate in Kupang general election (as a major) but they do not get enough supports from political party and even the man candidates get the supports. Listyaningsih stated that the grouping of dichotomist sociology roles if it is compared between man and woman, the domestic roles is used to the woman whereas the public roles are always stigmatized to the men [14]. Mattila dan Papageorgiou stated that in politics, participation is always approached by the social sources and social networks [15].

The political dynamics taking place in the context of legislative elections was that women did not meet the $30 \%$ quota as a confirmation for women. the number of women still lacks in the legislative field, so that women's political rights were not well planned. In the position of political parties, as well as women who do not appear in political parties as decision-makers, it is increasingly difficult for women to compete in democratic parties. Idris stated that the journey of woman through the politics arena is full of challenges, not easy and very dangerous [1]. Kerevel dan Atkeson stated that many people hold the gender stereotype about the suitability of woman in politic position [6].

Woman does not have chance to struggle her political rights. The participation of woman in Kupang as the decision/policy maker should be given the chance to struggle their rights. Lalchatuanthangi stated that the participation of woman in politics is very important to influence the decision, to promote the rights and strengthen woman's characters [17]. Geetha dan Indira stated that there was a strong relationship between status and power related to woman participation in decision taking [18].

And then, the factors which inhibit woman at Kupang East Nusa Tenggara Province to participate in politics are external and internal factor of woman. The factor that externally inhibit woman in politics is there is no support from political party and there is no support from society. And the factor which internally inhibit woman in politics is that woman think thinks that man always gets chances and also about economic factors. Idris uttered that there is obstacle faced by Minangkabau woman in politic leadership that is related to personal decision to be active in politics [1].

\section{CONCLUSION}

Patriarchy culture is still attached in the society so it also influences politics. The injustice to woman is still exist until now, it can be proved by the effort of woman to be candidate of Kupang's Major at 2017 but they did not get support from political party. The woman candidates have declared to participate in the election of regional head (executive) but they did not get enough supports from political party and also from society. Whereas, woman should face some obstacles to participate in politics, those are external obstacles and internal obstacles. External obstacle is woman did not get supports from society and the internal obstacle is woman feels that men have more good chances than them, and also they think that men have better economic opportunity.

\section{REFERENCES}

[1] N. Idris, "Perempuan Minangkahau dalam politik," Jurnal Humaniora, vol. 22, no. 2, pp. 164-175, 2010.

[2] S. Nimrah and Sakaria, "Perempuan dan budaya patriarki dalam politik (studi kasus kegagalan caleg perempuan dalam pemilu legislative 2014), “ The Politics, vol. 1, no. 2, pp. 173-182, 2015.

[3] H. Yusilia, "Pengarusutamaan gender (PUG) dalam tantangan budaya patriarki," Wardah, vol. 28, no. 15, pp. 195-201, 2014.

[4] T.R. Valentina, and R.E. Putra, "Posisi Perempuan Etnis Minangkabau dalam Dunia Patriarki di Sumatera Barat dalam Perspektif Agama, Keluarga dan Budaya," Jurnal Demokrasi, vol. 7, no. 1, 2008.

[5] E.M. Hutabarat, "Budaya patriarki dan perilaku politik perempuan dalam pemilu kepala daerah di Desa Marsangap tahun 2010,“"Dinamika politik, vol. 1, no. 3, pp. 7-12, 2012.

[6] P.S. Rawat, "Patriarchal Beliefs, Women's Empowerment, and General Well-being," VIKALPA, vol. 39, no. 2, pp. 43-55, 2014.

[7] V.M. Moghadam, Patriarchy and the politics of gender in modernising societies: Pakistan and Afghanistan. International Sosiology, vol. 7, no. 1, pp. 35-53, 1992.

[8] L.F.C. Ntoimo and U.I. Abanihe, "Patriarchy and Singlehood Among Women in Lagos, Nigeria," Journal of Family Issues,vol. 35, no. 14, pp. 1980-2008, 2014

[9] Y. Pranowo, "Identitas perempuan dalam budaya patriarkis: Sebuah kajian tentang Feminisme eksistensialis Nawal El Sa'adawi dalam novel "perempuan di titik nol"," Melintas, vol. 29, no. 1, pp. 56-78, 2013.

[10] G. Badawi, "Libraries and women's participation in Nigerian politics," IFLA Journal, vol. 33, no. 2, pp. 168-175, 2007.

[11] N. Nurmila, "Pengaruh budaya patriarki terhadap pemahaman agama dan pembentukan budaya.Karsa," vol. 23, no. 1, pp. 1-16, 2015.

[12] A. Rafni, "Profil dan Sikap Politik Perempuan Anggota DPRD di Sumbar Pasca Kuota 30\% Keterwakilan Perempuan dalam Pencalonan Anggota Legislatif,” Jurnal Demokrasi, vol. 7, no. 2, 2008.

[13] P.K. Panday, "Representation without Participation: Quotas for women in Bangladesh," International Political Science Revie, vol. 29, no. 4, pp. 489-512, 2008

[14] Listyaningsih, "Partisipasi perempuan dalam politik dan pembangunan di Banten," Jurnal Administrasi Publik, vol. 1, no. 2, pp. 143-166, 2010.

[15] M. Mattila and A. Papageorgiou, "Disability, perceived discrimination and political participation," International Political Science Review, vol. 38, no. 5, pp. 505-519, 2016.

[16] Y.P. Kerevel and L.R. Atkeson, "Reducing stereotypes of female political leaders in Mexico," Political research quarterly, vol. 68, no. 4, pp. 732-744, 2015.

[17] Lalchatuanthangi, "Participation of women in politics: A study of local councils and state Legislature," Indian journal of public administration, vol. 62 , no. 3, pp. 657-665, 2016.

[18] G.S. Geetha and R. Indira, "Women, Income Generation, and Political Capital in the Silk Industry in Karnataka," Gender, Technology and Development, vol. 14, no. 3, pp. 423-440, 2010. 